\title{
Neoliberalism and the transnational capitalist class
}

\author{
By William K. Carroll and Jean Philippe Sapinski
}

Pp. 25-35 in The Handbook of Neoliberalism, Kean Birch, Julie MacLeavy and Simon Springer, eds. London: Routledge, 2016.

\section{Introduction}

Although a literature on the transnational capitalist class (TCC) began to form in the 1970s, along with the first stirrings of neoliberal public policy, these intersecting phenomena have deeper lineages in elite capitalist networks, transnationalizing investment, and the interaction between the two. This chapter explores those lineages and interactions.

First, two matters of definition. As doctrine, neoliberalism asserts that 'free' markets 'are the most moral and the most efficient means for producing and distributing goods and services' (Cahill 2012, 111). As for the TCC, this concept is closely identified with the globalization of capitalism. Capital has been internationalizing for over half a millennium, but the $20^{\text {th }}$ century witnessed a more fully-fledged process of capitalist globalization. Particularly after World War Two (WWII), this involved two interrelated developments: 'an increase in the mobility of capital and an expansion of its geographical reach' (Kotz and McDonough 2010, 99). To invoke the classical Marxist distinction, these provided the structural basis - in capital accumulation - for a transnational capitalist class-in-itself. Concomitantly, however, the TCC developed the capacities to act as a class-for-itself, defining and pursuing its interests within a more transnationalized political field. Both aspects of TCC formation are tied to neoliberalism as a distinct form of advanced capitalism. We focus on the latter, but begin with an account of how the globalization of capital provided structural underpinnings for both neoliberalism and a TCC-in-itself.

In the decades following WWII economic globalization brought an enormous increase in cross-border investment, and by the late twentieth century the global financial market was awash in stateless moneycapital. Already in 1974, Hymer noted the class implications of these developments: '....an international capitalist class is emerging whose interests lie in the world economy as a whole and a system of international private property which allows free movement of capital between countries' (Hymer 1974, unpaginated).

The subsequent proliferation of transnational capital circuits saw worldwide export of goods multiply by a factor of 6.9 between 1970 and 2008, global foreign direct investment flows multiply by a factor of 48 between the 1970s and 2000s, and international bank loans multiply by a factor of 52 from 1977 to the peak level in 2008 (Duménil and Lévy 2012, 37). A TCC-in-itself, centred in the corporate owners and managers subtending the accumulation of capital on a transnational basis, developed in step with the internationalization of capital.

Our first cut at the relation between the TCC and neoliberalism considers the TCC as a class-in-itself. What is most significant in this context is that capital's enhanced mobility and transnational reach have 
conferred upon it an unprecedented 'structural power' (Gill and Law 1989). In the later decades of the $20^{\text {th }}$ century, as capitalist globalization ruptured the territorial coincidence of mass production and mass consumption, the conditions in advanced capitalist nation-states for high-wage, fordist capitalism and an expansive welfare state weakened. With increased international mobility and reach, transnational capital gained prominence, as investments deserted certain high-wage regions (e.g., 'rust-belt' cities like Detroit and Cleveland) in favour of locations in the global South offering low wages and high productivity. Quite apart from the collective agency of a TCC-for-itself, an increasingly internationalized economic circuitry has posed the threat of capital withdrawal for any jurisdiction whose policies stray very far from an investor-friendly policy paradigm prioritizing 'supply-side' issues (i.e., attracting and retaining an everincreasing stock of private investment to fuel 'economic growth') over 'demand-side' concerns (the maintaining of collective purchasing power of local populations) (Carroll 2003). Financialization - 'the growing weight of finance' in the economy (Krippner 2005, 174) - has further magnified capital's structural power, increasing the volume of capital that can move across national borders at the click of a mouse, as in currency speculation. As a class-in-itself, the TCC - those who own and/or control (the flow of) capital within an expanding transnational field - exercises structural power molecularly, in a multitude of market-mediated, profit-maximizing decisions that add up to a (shifting) verdict on particular places, states and industries. Once capital has attained unparalleled mobility and transnational reach, capitalists can play one national workforce, or local government off against another, bidding-down wages, taxes, labour standards, regulations and social programs in what can be described as a 'race to the bottom'. It is no coincidence that these are the stuff of neoliberal policy.

Thus, capitalist internationalization, and the closely linked formation of a TCC-in-itself, created a structural basis for neoliberal policy. In international competition, the state's predominant role shifted from that of promoting 'its' capitalists as leading agents of a national economy requiring robust effective demand (as in Keynesian and social-democratic industrial strategies), to that of promoting its territory as an attractive site for transnationally mobile investment intent on cutting its costs of production to the bone. This shift also meant a re-articulation of nationalist discourse. In organizing consent within a world-system of divided sovereignties, nationalist appeals to shared values and culture establish 'a supraclass identity' which, when aligned with the state, appears to transcend class struggle. The state seems to act 'in the interest of the national body' (Atkins 1986, 30). In the late $20^{\text {th }}$ century, the neoliberal rearticulation of national identity mobilized a 'national interest' around the ideology of international competitiveness, presenting 'international class dominance as national economic necessity' (Bryan 1995, 190). In short, the internationalization of capital and formation of a TCC-in-itself provided impetus for a paradigm shift in policy, and in the discourse of policy within imagined national communities. At the global level, the neoliberal shift has sought 'to harmonize a wide range of fiscal, monetary, industrial, and commercial policies among multiple nations, as a requirement for fully mobile transnational capital to move simultaneously, and often instantaneously, across numerous national borders' (Robinson and Harris 2000, 41).

Yet the narrative of a class-in-itself, amassing greater structural power as it subtends increasingly transnational capital circuits, only gives us the broadest outline of the relationship between the TCC and 
the development of neoliberalism, without highlighting the forms of collective agency through which the TCC became a leading protagonist in the political construction of neoliberalism. In the remainder of this chapter, we take up the roles that the TCC has played as a nascent class-for-itself, in the development of neoliberalism. In the next section we sketch the developing social-organizational basis for a TCC-foritself: the formation in the late $20^{\text {th }}$ century of a global corporate elite with extensive ties to a growing panoply of transnational policy groups dedicated to fashioning and promoting neoliberal initiatives. This social-organizational basis inheres in several key transnational sites of class leadership and consensus formation, which have developed in a century-long process, as well as in an elite network of transnational capitalists and the organic intellectuals that advise and support them. We next consider the question of fractions and distinct neoliberal projects within the TCC, showing that, although cumulatively integrated, the TCC is not an economically and politically homogeneous entity, just as neoliberalism itself is a variegated and evolving set of processes (Brenner, Peck and Theodore 2008). Finally, we take up the relationship between neoliberalism and the TCC in the context of the former's 'second life', after the financial meltdown of 2008.

\section{Policy-Planning and Elite Networks}

Three transnational policy-planning bodies have been since their inception key sites of TCC agency and have played a crucial role in promoting a neoliberal globalizing outlook. Each has mobilized the agency of transnational capitalists, ultimately leading to the consolidation of transnational neoliberalism from the 1970s onward. Funded by corporations and private foundations, these groups elaborate the general neoliberal worldview shared by transnational capitalists and diffuse it to constituencies beyond the TCC, a process Domhoff (2014) calls policy-planning. Concomitantly, they act as nodes of class cohesion among TCC members, creating solidarity among the owners/managers of capital and various aligned social forces. These two hegemonic mechanisms have amplified the TCC's capacity to act as a class-foritself while strengthening its structural power through policy initiatives that favour investor rights and the free flow of capital.

\section{International Chamber of Commerce}

The International Chamber of Commerce (ICC) was an early promoter of capitalist internationalism and of the free trade agenda embodied in what later came to be called neoliberalism. It was founded in 1919, in the wake of the First World War by a group of investment bankers portraying themselves as 'merchants of peace', who saw international trade as a means to avoid wars between nations. Today, the ICC boasts 'hundreds of thousands of member companies and associations in over 130 countries.' ${ }^{1}$ It has pursued a free market agenda since its inception, advocating market deregulation and opposing any form of governmental intervention in trade (Carroll and Carson 2003, 72). Beginning in the late 1980s, the ICC brought this outlook to global environmental politics, especially through its involvement in the 1992 Rio Earth Summit, which culminated in the creation of the World Business Council for Sustainable Development (WBCSD). Since the mid-1990s, it has promoted corporate self-regulation, and collaborated with the UN and the WBCSD to create the Global Compact in 2000.

\footnotetext{
Source: www.iccwbo.org/global-influence/icc-network/ (retrieved December 12, 2014).
} 
In accordance with its globalist outlook, the ICC has played a major role in organizing the TCC as a class-for-itself. Its executive board functions as a high-level forum where politically active transnational capitalists can meet, resolve disputes, and forge strategic consensus and a common international policy framework (Carroll and Carson 2003). Participation in the ICC board and other activities also works to integrate global capitalists located outside the capitalist core (Van der Pijl 1998), organizing the corporate elite on a truly global level. In the 1990s, the ICC adopted the explicit mandate to create solidarity among 'business' more generally, re-branding itself the 'World Business Organization'. It functions as a global network whose tentacles reach down to local chambers of commerce around the world, through its World Chambers Federation. While the ICC's executive board creates a 'horizontal' link among elite transnational capitalists, its multi-tiered organizational structure creates a 'vertical link' between the transnational capitalist interests of its TNC membership and its broad membership of locally and regionally anchored small and medium-sized enterprises (Carroll and Carson 2003, 73).

\section{Mont Pèlerin Society}

The Mont Pèlerin Society (MPS) was founded by Friederich von Hayek in 1947, in reaction to the emergent post-WWII state interventionist regime. It regrouped intellectuals supportive of the free market paradigm who were dissatisfied with Keynesian economic policy and sought to develop the neoliberal economic paradigm founded on free market ideals. The MPS played a different role than the ICC in the rise of neoliberalism and the rise of the TCC as a class-for-itself. Instead of regrouping elite capitalists, the MPS initially brought together a group of organic intellectuals organized around a core of common ideas and belief in the free market as the most efficient way to organize social life (Plehwe 2009). It thus constituted a conscious effort by militant intellectuals to solidify and disseminate the political ideas foundational to neoliberalism, so as to create 'a hegemonic project that could ultimately contribute to a neoliberal counter-revolution' (Carroll 2007, 43). The MPS quickly expanded its intellectual reach by organizing a global network of think tanks, later regrouped under the aegis of the Atlas Network, committed to furthering neoliberal free market thought and disseminating it among national policy networks around the globe.

Whereas the ICC supports an infrastructure that fosters direct interaction of transnational capitalists, the MPS builds long-term capacity for the development and diffusion of a 'neoliberal culture' to which its members are ideologically committed (Van der Pijl 1998). It does so by bringing together intellectuals, (mainly economists) as well as a smaller number of 'practical men' - corporate elites, politicians, journalists - committed to neoliberal principles (Carroll 2007, 44). Contrary to the ICC, the MPS was not established as a forum for discussion of different strategic options, but rather to propagate among policy circles what its members understood as unquestioned truth (Van der Pijl 1998). Such intellectual networking created a knowledge base around which the TCC mobilized as a class-for-itself when the Keynesian regime started to falter during the 1970s. An important elaboration of the MPS network is the Atlas Economic Research Foundation Network, founded in 1981 and comprising more than 400 marketoriented think tanks, most of them initiated and run with help from at least one MPS member (Plehwe 2009 , 35). In great part through the work of the MPS and its associated groups, the idea of a society 
organized solely around the market migrated from marginality in the post-WWII period to become part of the TCC's abiding common sense.

\section{World Economic Forum}

Established in 1971 by business policy expert Klaus Schwab, the World Economic Forum (WEF) was initially an informal gathering of European CEOs dedicated to discussing European corporate strategy in the world market (Carroll and Carson 2003, 74). It grew into a large-scale gathering of 'World Economic Leaders' in the early 1980s, including top transnational capitalists but also high-ranking politicians and heads of key international governmenal organizations (IGOs) that manage the neoliberal regime at the global level, such as the International Monetary Fund (IMF) and the World Bank. The WEF's core is organized around a group of elite capitalists, the 'Foundation Members', who are limited to 'the 1,000 foremost companies around the world' (WEF 2013, 7). From this core membership, the WEF extends to a broad array of satellite 'constituents' - scientists, academics, media leaders, public figures, artists and NGOs heads - who attend its yearly meetings in Davos, Switzerland.

In similar fashion to the ICC the WEF integrates capitalists from around the world. Originally mostly restricted to capitalists from core countries, the WEF gradually expanded its reach to include TCC members from all regions, and now holds regional meetings in China, India and Africa. The distinguishing characteristics of the WEF are two-fold. First, the breadth of the constituents invited to Davos helps diffuse the hegemony of the TCC across the political as well as the cultural realm of globalized society. Hence, beyond politicians, academics, and media figures, the WEF also seeks to establish the TCC's cultural leadership through the involvement of 'thought leaders' in Forum activities. It thereby seeks 'to integrate top level cultural leaders, with a proven track record of social activity and impact. ${ }^{2}$

Second, the WEF uses its broad reach to set the agenda for global governance. Its 'Network of Global Agenda Councils', created in 2008, attempts to define the agenda on many topics relevant to the TCC, from global economic growth to health, and to corporate social responsibility and environmental issues. The network regroups 'more than 1,500 of the world's most relevant experts from academia, business, civil society, government and international organizations,' hierarchically organized into 80 individual issue councils and six 'metacouncils'. The various councils interact extensively, monitoring trends, identifying global risks, discussing ideas and interconnections between issues, and developing recommendations that are integrated into World Economic Forum activities 'as well as into global decision-making processes. ${ }^{3}$

\section{The integrative role of corporate-elite networks}

The sprawling transnational networks of the ICC, MPS and WEF are complemented by a configuration that links many of the world's major capitalists to each other and to leading sites of neoliberal political agency. Indeed, the ICC, MPS and WEF represent just three nodes within a much broader network that rests on multiple types of links - corporate board interlocks created by directors sitting on the boards of

Source: www.weforum.org/issues/thought-leadership-through-art-culture-and-sport (Retrieved December 12, 2014).

Source: http://www.weforum.org/community/global-agenda-councils (Retrieved January 5, 2015). 
other corporations and policy groups, direct corporate funding of policy groups, and intercorporate ownership webs - all of which help integrate the TCC. Since the early 1970s, the consolidation of a transnational network of interlocking corporate boards, centred in the north Atlantic region formed 'a kind of superstructure bridging national corporate communities' (Carroll 2010, 225). Board interlocks that tie the largest global corporations together operate at two levels. First, they create an interorganizational network that provides a loose mechanism for the coordination of money flows, forming an infrastructure for the exercise of the TCC's allocative power. Second, they form an inter-personal network of interlocking directors who serve on common boards, thus strengthening class cohesion and contributing toward a shared worldview and sense of community - prerequisites for collective political action (Domhoff 2014).

Policy-planning groups such as the ICC and WEF have been linked into the transnational corporate network as leading corporate directors sit on their governance boards. They provide places for elite capitalists to plan political strategy, while enhancing the overall cohesion of the TCC as a class-for-itself. Carroll and Sapinski (2010) find that as the corporate-interlock networks have been thinning since the mid-1990s, 'policy boards have become more integrative nodes in the global corporate power structure' (530). Although the policy-planning network is centred upon the North-Atlantic zone, groups like the Trilateral Commission and the World Business Council for Sustainable Development include directors of corporations based in Japan and (more recently) high-growth countries of the global South, creating 'a complex organizational ecology, unified by a neoliberal consensus yet differentiated by regional and other issues and interests' (530).

The organizations and networks discussed in this section furnish crucial mechanisms in the formation of a TCC-in-itself, and underline the close relationship between that formation and the neoliberal paradigmshift. However, despite all this, the TCC is far from a unified entity, but is transected by multiple fractionations and competing strategic visions. These will be discussed in the next section.

\section{Fractions and projects}

The notion of a TCC-for-itself implies, as we have seen, the development of institutional forms through which collective interests can be articulated and collective agency exercised. However, since capital itself is divided - into many competing units and (despite global governance frameworks) within an international system of divided sovereignties - the issue of how fractional divisions within capital bear upon the relationship between the TCC and neoliberalism merits further scrutiny.

As early as 1983, Kees van der Pijl offered a theoretically grounded analysis of capitalist class fractions in the formation of a neoliberal hegemonic project. In his initial formulation, Van der Pijl $(1983,1984)$ noted that projects like fordist-Keynesianism or neoliberalism take shape on the basis of distinct vantage points or fractional perspectives which the structural division of capital between production and circulation makes available: those of productive capital and money capital. Intrinsic to production are the technical issues surrounding the creation of use value, in a word, planning. Intrinsic to circulation is the free movement of goods and capital, especially in money form, and thus the convertibility of currencies. The money-capital perspective posits 'a system of harmony and progress as long as through 
the price mechanism, the rate of profit remains the exclusive regulatory device' (Van der Pijl 1983, 22). The productive-capital perspective constructs an interest from the position of the industrialist, who is willing 'to subordinate the orthodoxy of the market mechanism to a strategy better suited to the real socialization of the productive forces' (Van der Pijl, 1983, 28).

These fractional standpoints underpin definite political projects that take shape through the efforts of organic intellectuals in universities, government commissions, and policy-planning groups $(1983,14,20)$. It is in making a fractional perspective comprehensive - 'an effective vector of class formation within and beyond the bourgeoisie' $(1984,12)$ - that a project becomes hegemonic as fractional interests are transcended and a general interest constructed.

Beginning with the Pinochet dictatorship in Chile (1973-1990), and continuing through the Thatcher and Reagan initiatives in the 1980s, neoliberalism was consolidated as a hegemonic project. In positing 'sound money', free labour, and unimpeded international circulation (and in marginalizing the productive-capital concern with planning), neoliberalism presented the perspective of money-capital as a general interest around which the sectoral interests of different capital fractions could be assembled (Van der Pijl 1986, 3). Its subsequent expansion, from the Chilean beachhead and the Lockean heartland of anglophone capitalism to a transnational hegemonic project for global capitalism and the TCC, was facilitated by financialization (itself a product of neoliberal policy that cumulatively skewed profit distribution in favour of short-term financial assets as opposed to fixed-capital industrial investment), by the consolidation of global governance around the so-called Washington Consensus promoting investor rights as 'free trade' and mandating austerity programs in the debt-ridden global South, and by the collective agency of a TCC centred in the North Atlantic and including many strata of organic intellectuals and a growing assemblage of policy-planning groups (Van der Pijl 1998).

A significant chapter in this process has been the neoliberalization of continental Europe and the closely associated making of a European TCC. Indeed, more than anywhere else, Europe has witnessed the deepest process of TCC formation over the past three decades. Van Apeldoorn has documented the leading role of European capitalists in 'the creation of a transnational space for capital in which the latter's rule is established precisely by preserving the formal sovereignty of member states while subordinating their democratic governance to the dictates of the single market' $(2013,189)$. Interestingly, this project has been championed by the European Round Table of Industrialists (ERT), which after its founding in 1983 became the premier policy-planning body of Europe's TCC. This apparent anomaly shows how, as neoliberalism gained ideological hegemony the money-capital perspective was taken up as a general point of view within (and beyond) the capitalist class.

As the global financial crisis unfolded from 2007 onward, the spatialized contradictions of neoliberal Europe surfaced, particularly in the austerity programs imposed upon Europe's debt-ridden southern periphery, a strategy for shoring up financial institutions and accumulation in Europe's affluent north while shrinking the economies of the south (and rendering their debt reduction 'ever more elusive' (Van Apeldoorn 2013, 198)). The challenges to neoliberal hegemony (in Europe and more generally) and the tendency for that hegemony to give way to 'a new authoritarian neoliberalism in which democracy is hollowed out' $(2013,199)$ are taken up in the last section of this chapter. 
Another major contribution to scholarship on neoliberalism and the TCC is William Robinson's 'theory of global capital' (Robinson 2004, 2012). Robinson identifies globalization with the formation of a TCC and transnational state, in opposition to 'national' fractions of capital. The key statement of this position was made in Robinson and Harris's 2000 article, which sees capitalist globalization as replicating, on a world-scale, the nation-building stage of early capitalism: constructing an integrated market with common laws, currency, taxes, 'and political consolidation around a common state', in this case a transnational state apparatus constituting 'a new legal and economic superstructure for the global economy' $(2000,42)$. This article distinguishes three neoliberal strategic ('factional') positions within the TCC, described as free-market conservative, neoliberal structuralist, and neoliberal regulationist. The first position ideologically opposes any state intervention in economic relationships beyond upholding private property rights, whereas the last supports state intervention to reduce the worst economic and social contradictions of neoliberalism, so as to thwart political contestation and stabilize the regime. In between them, the neoliberal structuralist faction, dominant among the TCC according to Robinson and Harris, favours minimal economic intervention to contain crises, for example through bailouts for banks when their collapse would threaten the neoliberal regime itself.

Robinson's reading of globalization as transnational political consolidation posits a major fractional division between national capitalists, whose business practices are largely contained within national borders, and the TCC. Robinson (2012) holds that, within countries, transnational capitalist fractions were successful in the 1980s and 1990s in wresting state power from national fractions, and that neoliberal globalization has proceeded under their direction. Such a zero-sum scenario may fit with some experiences, but it encounters problems as a general account, particularly when we consider that it has often been local and national capital that has pressed, through Chambers of Commerce and other market-oriented groupings, for low tax, laissez-faire regimes to limit their wage costs (Carroll 2012). Our earlier discussion showed how the TCC has long been a key participant in developing global neoliberal policy networks. Yet this does not discount the extensive role national fractions of capital have played in bolstering neoliberalism through their support of nationally-based think tanks and political parties, as exemplified by the MPS-supported Atlas Network, mentioned earlier.

In practice, the distinction between 'national' capitalists and 'transnational' capitalists is blurry. Van Apeldoorn and De Graaff's (2012) analysis of the corporate affiliations of key cabinet-ranking and senior advisors in the Clinton, Bush and Obama administrations revealed not only a remarkable number of connections into the 'national' American corporate community, but a strong presence of US-based transnational capital. For them the overwhelming predominance of the latter, at once national and transnational, at the heart of the US capital-state nexus, helps explain the strong US commitment to transnational neoliberalism within a 'grand strategy' that in fact 'reflects the interests of US transnational capital' (Van Apeldoorn and De Graaff 2012, 600).

Thus, despite tendencies toward becoming a class-for-itself, the TCC does not express a single unified volition. Contradictory dynamics still issue from the fractional perspectives of money capital and industrial capital, and neoliberal thought harbours multiple approaches to the best strategy for maintaining TCC dominance. Certain national dynamics may also come into contradiction with now 
globalized circuits of accumulation, though the prominence of these tensions is not as clear-cut as first suggested by Robinson and Harris (Carroll 2013). The next section discusses how these processes have played out since the last major crisis to have rocked the neoliberal regime.

\section{Second life: The 2008 financial meltdown and beyond}

The global economic crisis - cascading from the massive devaluation of bundled assets tied to the US mortgage market in 2007 to insolvent investment banks, crashing stock markets and by late 2008 a 'frozen' international financial system threatening worldwide depression - was greeted by many as a sign of neoliberalism's demise. Although in the aftermath of the financial meltdown, some observers announced neoliberalism's demise, instead of 'post-neoliberalism' the crisis actually granted neoliberalism a second life (Mirowski 2013; Bruff 2014; Springer 2015). Here, we first consider the changes in the TCC associated with the mutation of transnational neoliberalism in the years surrounding the global crisis, and then we examine implications of neoliberalism's post-2008 second life for the TCC as a class-for-itself.

On the first point, Van der Pijl and Yurchenko (2014) offer an interpretation that adds nuance to the former's analysis of the connection between neoliberalism and TCC formation. They periodize the neoliberal era not in terms of policy content (the familiar 'rolling back' and 'rolling out' phases - see Peck and Tickell 2002) but in terms of the social class complexes and circuits of accumulation favoured by each version. In neoliberalism's prehistory, during the era of fordist-Keynesian class compromise, capitalism's 'lead circuit' was that of productive capital, furnishing the basis in the global North for a general interest in robust national economies. But in the 1970s, as productivity gains in the worldsystem's core fell behind wage increases, depressing profits, corporations shifted production to low-wage zones. Concurrently, the circuit of money-capital gained global sweep and the swelling volume of internationally mobile money capital fed inflation. The Volcker Shock of 1979, which inaugurated the neoliberal roll-back by putting brakes on the expansion of money (thus forcing up interest rates), was aimed at restoring the discipline of capital at home while obliging indebted states to avoid default by privatizing assets. It thereby 'widened the sphere of capital accumulation under the auspices of interestbearing money capital' (Van der Pijl and Yurchenko 2014, 8).

The objective in this 'systemic' phase of neoliberalism was to restore profitability via real accumulation, in no small measure through attacks on organized labour for which the Reagan and Thatcher regimes became notorious. But as financialization created an ever-expanding volume of derivatives, neoliberalism 'slowly mutated into a "predatory" version in which real capital accumulation becomes a secondary consideration altogether' $(2014,9)$. In neoliberalism's predatory phase, it is money-dealing capital, claiming profit through speculative arbitrage, which dominates the accumulation process. As shown in the crisis of 2007-2009, state authorities are deeply implicated in this process: when the crash comes, their bail-outs refuel the bubble economy, indicating an alignment between predatory neoliberalism and ascendant money-dealing capital. Yet socializing bank losses turns a crisis of money-dealing capital into a crisis of public finance. 'Austerity, the asset-stripping of entire societies, thus becomes the downside of refueling speculative money-dealing capital' $(2014,18)$. 
For the TCC, the transition, in neoliberalism's predatory phase, to a fully financialized capitalism brought a weakening of corporate-interlock networks, both national and transnational, as relationshipbased financing via interest-bearing bank loans gave way to transaction-based finance through securitized financial paper (Carroll 2010). In the emergent form of neoliberal capitalism, the TCC continues to be well-organized politically, through its core policy-planning organs, but the corporate-interlock network thins, as corporate governance becomes a matter of speculative capital market control rather than corporate self-regulation (Van der Pijl and Yurchenko 2014). As we have seen, the continuing proliferation of transnational policy groups and neoliberal think tanks offers a more directly political form of TCC social organization, useful in constructing and championing pro-market policies.

Predatory neoliberalism, however, faces a thinning basis for popular consent. Van der Pijl and Yurchenko (2014) describe a move from a (narrow) class compromise, under systemic neoliberalism, between capital and the asset-owning middle classes to an exclusivist, oligarchic order. As neoliberalism becomes more predatory, it also becomes more authoritarian (Bruff 2014): societal asset-stripping - the project of 'total privatization' (Albo and Fanelli 2014) - can provoke intense resistance, requiring a ratcheting-up of the free market/strong state relation that was already deeply inscribed in the Thatcherite version of neoliberalism (Gamble 1988). Surveillance, the criminalization of dissent, the militarization of policing and the framing by neoliberal governments of 'protestors, and political opposition in general, as a threat to economic recovery and competitiveness' (Albo and Fanelli 2014, 21-22) become the order of the day.

Yet a more predatory and authoritarian neoliberalism does not negate the need for the dominant class to win a modicum of consent from subaltern groups (see e.g. Springer 2009). Indeed, the weakening of neoliberal hegemony needs to be viewed in conjunction with 'full-spectrum' neoliberalism as it has matured in the think tanks and related groups supported by the TCC: a spectrum of short, middle and long-term initiatives organized around 'the immutable solidity of the market' (Mirowski 2013, 342). These various strategies do not fit seamlessly into a monolithic program - they may even contradict each other on the surface; and, we might add, they attract different factions and fractions of the TCC as their sponsors and champions.

For instance, 'the phenomena of "science denialism," "carbon permit trading," and the nascent science of "geoengineering" are not three unrelated or rival panaceas, but together constitute the full-spectrum neoliberal response to the challenge of global warming' (Mirowski 2013, 337). Transnational capitalists like the billionaire Koch brothers (inventors of oil derivatives, heavily invested in Alberta's tar sands and bankrollers of the US Tea Party) trumpet climate-change denial and laissez-faire conservatism, defending the sanctity of the market and of business-as-usual in the short term. ${ }^{4}$ Carbon trading finds favour within the financial sector, as a mid-range strategy, aligned with neoliberal structuralism, which creates new instruments of financialization. Geoengineering (sponsored by such billionaires as Bill Gates and Richard Branson and implying in its global scale some degree of neoliberal regulation) mobilizes science and industry for longer-term investments in absorbing/sequestrating carbon or in reflecting sunlight away from the Earth. ${ }^{5}$ Here we can see how in full-spectrum neoliberalism, the TCC's laissez-faire

See the investigative reports and related material at the International Forum on Globalization's site http://kochcash.org. The World Business Council on Sustainable Development, including CEOs of financial and industrial TNCs, is an important site for mediating across this spectrum. A longstanding advocate of voluntary corporate guidelines, it has in 
conservative, structural and regulationist factions, and its financial and industrial fractions, mobilize around variegated initiatives that have in common the reproduction of neoliberal capitalism on an expanding scale. The relationship between neoliberalism and the transnational capitalist class, whether in its formative era, its heyday or now its second life, has been both complex and fateful.

the past decade elaborated principles for carbon pricing and trading, and in September 2014 announced its support of carbon capture and storage. See http://www.wbcsd.org/changing-pace/business-perspectives/energyandpower.aspx and http://www.wbcsd.org/Pages/eNews/eNewsDetails.aspx?ID=16323 (retrieved 8 January 2015). 


\section{References}

Albo, G., and C. Fanelli. 2014. Austerity against Democracy: an authoritarian phase of neoliberalism? Toronto: Socialist Project. www.socialistproject.ca/documents/AusterityAgainst Democracy.pdf (last accessed 2 January 2015).

Atkins, F. 1986. Thatcherism, Populist Authoritarianism and the Search for a new left Political Strategy. Capital \& Class 28:25-48.

Brenner, N., J. Peck, and N. Theodore. 2010. Variegated Neoliberalization: Geographies, Modalities, Pathways. Global Networks 10:182-222.

Bruff, I. 2014. The Rise of Authoritarian Neoliberalism. Rethinking Marxism 26:113-29.

Bryan, D. 1995. The Chase Across the Globe: International Accumulation and the Contradictions for Nation States. Boulder (CO): Westview Press.

Cahill, D. 2012. The Embedded Neoliberal Economy. In Neoliberalism: Beyond the Free Market, eds. D. Cahill, L. Edwards, and F. Stilwell, 110-27. Cheltenham, UK: Edward Elgar.

Carroll, W. K. 2003. Undoing the End of History: Canada-Centred Reflections on the Challenge of Globalization. In Global Shaping and its Alternatives, eds. Y. Atasoy and W. K. Carroll, 33-55. Aurora, Ontario: Garamond Press.

_. 2007. Hegemony and Counter-Hegemony in a Global Field. Studies in Social Justice 1(1):36-66. . 2010. The Making of a Transnational Capitalist Class: Corporate Power in the 21st Century. London and New York: Zed Books. . 2012. Global, Transnational, Regional, National: The Need for Nuance in Theorizing Global Capitalism. Critical Sociology 38(3):365-71.

. 2013. Whither the Transnational Capitalist Class? Socialist Register 50:162-88.

Carroll, W. K., and C. Carson. 2003. Forging a New Hegemony? The Role of Transnational Policy Groups in the Network and Discourse of Global Corporate Governance. Journal of World-Systems Research 9(1):67-102.

Carroll, W. K., and J. P. Sapinski. 2010. The Global Corporate Elite and the Transnational PolicyPlanning Network, 1996-2006: A Structural Analysis. International Sociology 25(4):501-38.

Domhoff, G. W. 2014. Who Rules America? The Triumph of the Corporate Rich. 7th ed. New York: McGraw-Hill.

Duménil, G., and D. Lévy. 2012. The Crisis of Neoliberalism as a Stepwise Process: From the Great Contraction to the Crisis of Sovereign Debts.In Neoliberalism: Beyond the Free Market, eds. D. Cahill, L. Edwards, and F. Stilwell, 31-53. Cheltenham, UK: Edward Elgar.

Gamble, A. 1988. The Free Economy and the Strong State. London: Macmillan.

Gill, S. R., and D. Law. 1989. Global Hegemony and the Structural Power of Capital. International Studies Quarterly 33(4):475.

Hymer, S.. 1974. International Politics and International Economics: A Radical Approach (mimeographed), published posthumously in Monthly Review 29(1). 
Kotz, D. M., and T. McDonough. 2010. Global Neoliberalism and the Contemporary Social Structure of Accumulation. In Contemporary Capitalism and its Crises, eds. T. McNonough, M. Reich, and D. M. Kotz, 93-120. New York: Cambridge University Press.

Krippner, G. R. 2005. The Financialization of the American Economy. Socio-Economic Review 3:173208.

Mirowski, P. 2013. Never Let a Serious Crisis Go to Waste: How Neoliberalism Survived the Financial Meltdown. London: Verso Books.

Peck, J., and A. Tickell. 2002. Neoliberalizing Space. Antipode 34(3):380-404.

Plehwe, D. 2009. Introduction. In The road from Mont Pèlerin: The making of the neoliberal thought collective, ed. P. Mirowski and D. Plehwe. Cambridge, MA: Harvard University Press.

Robinson, W. I. 2004. A Theory of Global Capitalism. Baltimore: Johns Hopkins University Press. . 2012. Global Capitalism Theory and the Emergence of Transnational Elites. Critical Sociology 38(3):349-63.

Robinson, W. I., and J. Harris. 2000. Towards a Global Ruling Class? Globalisation and the Transnational Capitalist Class. Science \& Society 64(1):11-54.

Springer, S. 2009. Renewed Authoritarianism in Southeast Asia: Undermining Democracy through Neoliberal Reform. Asia Pacific Viewpoint 50(3):271-76.

Springer, S. 2015. Post-neoliberalism? Review of Radical Political Economics 47(1):5-17.

Van Apeldoorn, B. 2013. The European Capitalist Class and the Crisis of Its Hegemonic Project. Socialist Register 50:189-206.

Van Apeldoorn, B., and N. de Graaff. 2012. The Limits of Open Door Imperialism and the US StateCapital Nexus. Globalizations 9(4):593-608.

Van der Pijl, K. 1983. Imperialism and Class Formation in the North Atlantic Area. Doctoral Dissertation, University of Amsterdam.

. 1984. The Making of an Atlantic Ruling Class. London: Verso. . 1986. Neoliberalism vs. Planned Interdependence. Concepts of Control in the Struggle for Hegemony. Paper presented at the Conference on Interdependence and Conflict in the International System, Polemologisch Instituut, Groningen, November 19-21.

. 1998. Transnational Classes and International Relations. London: Routledge.

Van der Pijl, K., and Y. Yurchenko. 2014. Neoliberal Entrenchment of North Atlantic Capital: From Corporate Self-Regulation to State Capture. New Political Economy.

DOI:10.1080/13563467.2014.923827.

World Economic Forum. 2013. Annual Report 2012-2013. Geneva: World Economic Forum. 